\title{
William Morton Wheeler, Hon.F.R.S.E.
}

In the passing of William Morton Wheeler, Emeritus Professor of Entomology at the University of Harvard, the world of science in general, and entomology in particular, has lost one of her greatest men, a man honoured in his own country, and well known and admired for the excellence of his work far beyond the confines of the United States Wheeler was born at Milwaukee, State of Wisconsin, on March I9, I865, and died suddenly at Cambridge, Massachusetts, on April 19, 1937.

Wheeler's early schooling was obtained at the German-American Normal School, Milwaukee, and later at Engelmann's German Academy. As a boy he showed an interest in natural history, in collections in museums-later he was a great collector himself-in nature study and open-air sights and sounds.

For a short time he was engaged in routine museum work at Rochester, U.S.A., arranging and cataloguing the collections, invertebrate and vertebrate, but resigned this work on his appointment in 1865 as Teacher of German and Physiology at Milwaukee High School. Here the Principal was Dr G. W. Peckham, whose wasp studies are'well known. Peckham was certainly an influence in giving Wheeler a bias towards the study of insects. Near Milwaukee High School was the Allis Laboratory under the directorship of Professor C. O. Whitman, who was another influence in Wheeler's love for natural history. One of Whitman's assistants, Dr William Patten, gave Wheeler instruction in research methods and turned him on to work at insect embryology. This work was to bear fruit later on when Wheeler, working with a Scholarship at Clark University, graduated Ph.D. in I892, with a thesis on The Embryology of Insects.

Before this, however, from I 887 to I 890 , Wheeler had held the post of Curator of the Milwaukee Public Museum.

In I893-94 Wheeler visited Europe to work at Wurzburg under Boveri, an inspiring teacher, famous at the time for his work on the cell, then at Liège, and then to occupy one of the tables at the Naples Zoological Station. A friend has described to me his attitude of wonder when Wheeler demonstrated to him under the microscope the fertilisation of the eggs of an echinoderm.

Wheeler returned to the United States as Assistant-Professor of 
Embryology in the University of Chicago, leaving this post in I899 on his appointment to the University of Texas.

In 1903 Wheeler was appointed Curator of Invertebrate Zoology at the American Museum of Natural History, New York, and in Igo8 he joined the staff of Harvard University as Professor of Entomology, later also acting as Curator of Insects at the Museum of Comparative Zoology. During Professor Wheeler's tenure of the Chair at Harvard University he acted from 1915 to 1929 as Dean of the Bussey Institution, a Graduate Research School of the University in Applied Zoology.

While at Harvard, Wheeler, by invitation, acted as Exchange Professor in the University of Paris, his proficiency in French and German making the task easy and grateful to him.

Professor Wheeler's research work-there is a list of over 460 published papers-covers a wide field in zoology (taxonomic, morphological, embryological), while he wrote with pronounced opinions on evolution, but his latest work was devoted to insects and especially ants. His interest in ants, originally stimulated while at the University of Texas, grew with the years and took him in their study not only over North and South America but all over the world. I have had the pleasure of enjoying Wheeler's leadership in a field excursion, and an intimate friend of Wheeler who was his companion in many an ant foray in widely separated parts of the world wrote to me describing Wheeler's insatiable curiosity and constant enthusiasm. Companions had need of enthusiasm too, for the memory of wounds from Eciton ants lingered long, or, as my friend put it: "I never knew what ants could be until Wheeler led us into a tangle of inhabited (i.e. with their bodyguard of ants in position) Bull Horn Acacias." Wheeler was always finding things. Once the guest of a close friend in South Florida, Wheeler's host looked in to greet him on the first morning after his arrival. Wheeler had already discovered the nest of some mushroom-growing ants.

Wheeler's field-work and observations on ants in every phase of their often extraordinary life-history and habits, and his interest in other social insects, led naturally to studies in ecology and sociology and comparative psychology. Hence the authority of his scientific writings with their wealth of illustration and width of interpretation.

Among Wheeler's published works may be named Ants, their Structure, Development and Behaviour (I9IO) in the Columbia University Biological Series; Social Insects: their Origin and Evolution; Foibles of Insects and Men; Demons of the Dust: A Study of Insect Behaviour; Colony Founding among Ants. One of the chapters in Foibles of Insects and Men consists of an address (also published in Science, vol. lvii, P.R.S.E. - VOL. LVII, I936-37, PART IV. 
January 19, 1923) entitled "The Dry Rot of our Academic Biology." Apart from its relation to the teaching of biology-and everybody is interested in biology just now-the address is worth reading as an example of Wheeler's power with the pen. In this address, Wheeler defines his own attitude to research and to teaching, with a great preference for research. But his reference to his oversight of his students in training is too modest, for many graduates in prominent posts to-day bear willing testimony to what they owe to Wheeler for his sympathetic bearing and help in his laboratory.

A profound scholar, a capable linguist, steeped in the literature and philosophy of West and East, a world traveller with a wonderful record of work, Wheeler had every temptation to "wear the nodding plumes of intellectual conceit," but he remained a modest, human man, practising at home an easy natural hospitality, enjoying the humour and the stories of his friends and ready to tell a good story himself. Wheeler's work will continue to live, but his friends and colleagues will miss him much.

Professor Wheeler received an Honorary Doctorate from the Universities of Chicago (1916), California (1928), Harvard (1930), Columbia (1933). Among other honours he was made an Officer in the Legion of Honour. The Royal Entomological Society of London, the Entomological Society of France, and the Entomological Society of Belgium elected him as an Honorary Member.

He was elected an Honorary Fellow of the Royal Society of Edinburgh in 1936 .

R. S. M. 